\title{
Perlukah Central Venous Cathether (CVC) untuk Pengelolaan Anestesi Reseksi Tumor Pineal Body dengan Posisi Parkbench?
}

\author{
Kulsum, Zafrullah Khany Jasa, Fachrul Jamal \\ ${ }^{*}$ Departemen Anestesi dan Terapi Intensif Fakultas Kedokteran UNSYIAH - Rumah Sakit Umum Zainoel Abidin \\ Banda Aceh
}

\begin{abstract}
Abstrak
Tumor pineal body di Indonesia termasuk kasus yang jarang dengan insidens $10 \%$ dari seluruh tumor otak. Reseksi tumor otak bisa dilakukan dengan berbagai posisi tergantung letak tumor, operator dan fasilitas yang tersedia. Perdarahan pada kasus tumor pineal body sekitar 5-10\% sehingga pemasangan Central Venous Catheter (CVC) tergantung kebutuhan saat operasi. Tujuan laporan kasus ini untuk mengetahui apakah harus dipasang CVC pada kasus tumor otak. Pengelolaan operasi reseksi tumor pineal body dilakukan dengan posisi parkbench tanpa dipasang alat CVC dengan manajemen neuroanestesi. Seorang anak laki laki 10 tahun, berat badan $21 \mathrm{~kg}$ mengeluh nyeri kepala hebat, mual muntah, kejang kejang, mata menonjol, pandangan kabur, badan spastik telah dilakukan ventriculo peritoneal shunt (VP-Shunt) 3 bulan yang lalu. Premedikasi menggunakan midazolam dan fentanyl. Induksi menggunakan propofol dan ada penambahan saat laringoskopi dan intubasi. Fasilitas intubasi dengan atracurium. Pemeliharaan anestesi dengan $\mathrm{O}_{2}+$ udara + sevofluran dengan fraksi oksigen 50\% + Propofol dan atracurium secara kontinyu. Monitoring tanda vital (tekanan darah, denyut jantung, frekuensi nafas, saturasi oksigen, jumlah dan warna urin) serta end tidal $\mathrm{CO}_{2}$. Hasil reseksi tumor pineal body selama 4 jam hemodinamik relatif stabil, tekanan darah sistolik berkisar 90-10 mmHg, tekanan darah diastolik 40-60 mmHg. Pengelolaan kasus reseksi tumor pineal body dengan posisi parkbench tanpa pemasangan CVC tetap masih bisa dilakukan dengan syarat monitoring ketat dan atasi segera setiap permasalahan yang terjadi.
\end{abstract}

Kata kunci: CVC, posisi parkbench, tumor pineal body

JNI 2019;8 (1): 24-32

\section{Does it Need CVC for the Management of The Pineal Body Tumor with Parkbench Position?}

\begin{abstract}
Pineal body tumors in Indonesia is a rare cases with 10\% incidence of all brain tumors. Brain tumor resection can be done with various positions depending on the location of tumors, operators and facilities available. Bleeding in case of pineal body tumor is about $5-10 \%$ so the installation of Central Venous Catheter (CVC) depends on the need for operation. The purpose of this case report is to determine whether CVC should be installed in cases of brain tumors. The management of pineal body tumor resection surgery is done by parkbench position without CVC with neuroanesthesia management. A 10 -year-old boy weighing $21 \mathrm{~kg}$ complained of severe headache, nausea, vomiting, convulsions, prominent eyes, blurred vision, spastic body had been done Ventriculo Peritoneal Shunt (VP Shunt) 3 months ago. Premedication using midazolam and fentanyl. Induction uses propofol and there is addition in laryngoscopy and intubation. Intubation facility with atracurium. Maintenance of anesthesia with $\mathrm{O} 2+$ water + sevofluran with $50 \%$ + oxygen fraction + Propofol and atracurium continuously. Monitoring of vital signs (blood pressure, heart rate, breath frequency, oxygen saturation, amount and color of urine) and end tidal CO2. Resection of pineal body tumor for 4 hours hemodynamically relatively stable, systolic blood pressure ranged from $90-110 \mathrm{mmHg}$, blood pressure diastolic 40-60 mmHg. Management of pineal body tumor resection case with parkbench position without CVC installation still can be done with tight monitoring condition and solve immediately every problem that happened.
\end{abstract}

Key words: CVC, parkbench position, pineal body tumor

JNI 2019;8 (1): 24-32 


\section{Pendahuluan}

Tumor Pineal Body di Indonesia termasuk kasus yang jarang ditemukan. Insidensi tumor otak meningkat sebanyak $25 \%$ selama dua dekade terakhir di seluruh dunia karena sifatnya yang jinak alami dan hasil operasi yang diharapkan sempurna setelah eksisi total. Perkembangan teknik operasi mikro yang semakin baik serta perkembangan neuroanesthesi dan critical care yang semakin canggih membuat reseksi tumor yang agresif menjadi pilihan untuk manajemen tumor regio pineal dan ventrikel III. Jaringan otak tertutup oleh tulang cranium disertai hubungan kontinu dari aliran darah dan volume jaringan otak, maka resiko perdarahan dan edema sangat tinggi. Pada operasi reseksi tumor tanpa pendekatan anestesi yang tepat, dapat meningkatkan resiko edema dan perdarahan otak karena manipulasi operasi. Adanya komplikasi emboli udara bisa diketahui dari monitoring end tidal $\mathrm{CO}_{2}$, dan umumnya emboli udara yang terjadi dapat diambil melalui Central Venous Catheter (CVC). ${ }^{1}$

Gejala-gejala klinis tumor otak umumnya tergantung pada lokasi anatomi yang terlibat. Tiga gejala utama yang sering terjadi yaitu nyeri kepala, perubahan status mental, dan kelumpuhan. Selain memfasilitasi dilakukannya pembedahan, dokter anestesi juga perlu melakukan tindakan dibidang neuroanestesi yang dapat mengendalikan tekanan intrakranial dan volume otak, melindungi jaringan saraf dari cedera dan iskemia dengan melakukan teknik brain protection serta mengurangi jumlah perdarahan yang terjadi selama operasi berlangsung. Ada beberapa hal yang penting untuk dihindari selama pembedahan, yaitu hipoksemia, hiperkapnia, anemia, dan hipotensi karena akan berdampak negatif terhadap susunan saraf pusat dan juga luaran operasi.

Sebagai upaya mencegah hal-hal tersebut, harus dipertahankan mekanisme autoregulasi otak dan respon terhadap $\mathrm{CO}_{2}$ darah otak, aliran darah otak cerebral blood flow (CBF) akan mengikuti tekanan perfusi otak cerebral perfusion pressure (CPP) secara pasif. Bila CBF sangat berkurang (MAP $<50 \mathrm{mmHg}$ ) bisa terjadi serebral iskemia. Di atas batas normal (MAP $>150 \mathrm{mmHg}$ ), tekanan akan merusak daya kontriksi pembuluh darah dan CBF akan naik tiba-tiba. Pada tahap lanjut terjadilah kerusakan sawar darah otak dan terjadi edema serebral dan kemungkinan perdarahan otak. $^{2}$

\section{Kasus}

\section{Anamnesis}

Seorang anak laki laki 10 tahun dengan berat badan $21 \mathrm{~kg}$ mengeluh nyeri kepala hebat, mata menonjol dan pandangan kabur, sering kejang kejang sehingga badannya spastik, mual muntah, pertumbuhan kurang serta sering sakit sakitan dan selalu dibawa berobat ke dokter spesialis anak. Pasien dilakukan ventriculo peritoneal shunt 3 bulan yang lalu

\section{Pemeriksaan Fisik}

Hasil pemeriksaan airway bebas, tidak terdengar suara tambahan apapun. Breathing gerak dada simetris, frekuensi napas $20 \mathrm{x} / \mathrm{m}$, tidak terlihat sesak rhonki dan wheezing tidak dijumpai. Sirkulasi tekanan darah 100/65 mmHg, frekuensi nadi 95 kali per menit, capillary refill $<2$ detik. Defisit neurologis dijumpai pandangan kabur dengan visus $1 / 60$, nyeri kepala dan spastik pada

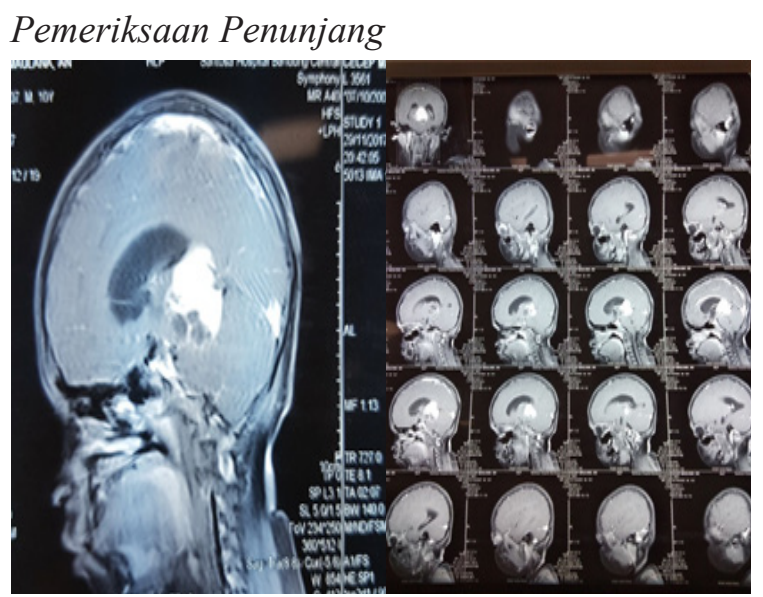

Gambar 2.1 Hasil bacaan CT Scan: didapati tumor pineal body

otot rangka. Kesadaran penuh dan tidak ada defisit neurologis pada saraf kranialis lainnya.

\section{Pemeriksaan Laboratorium}

Hb 9.7 g/dl, Ht 28, L 8000, T 250.000. Pt/aPTT/: 
$11,0(9,7) / 23,6(23,5)$ e:135/3,6/99 , GDS 114 Ur/ cr: $18 / 0,72$. Rontgen thoraks tidak ada kelainan pada jantung dan paru.

\section{Pengelolaan Anestesi}

Preoperasi pasien dilakukan pengembalian cairan puasa dan dipaatikan jalur intravena lancar. Hemodinamik prainduksi yaitu tekanan darah 100/50 $\mathrm{mmHg}$, frekuensi nadi 95 kali per menit, frekuensi napas 20 kali per menit dan saturasi $\mathrm{O}_{2}$ $100 \%$. Premedikasi menggunakan midazolam $1 \mathrm{mg}$ dan fentanyl $40 \mathrm{mcg}$. Lidocain $20 \mathrm{mg}$ diberikan untuk mengatasi gejolak hemodinamik dan timbulnya reflex jalan nafas. Deksametason 5 mg diberikan untuk mengatasi perifokal oedem.

Induksi menggunakan propofol $40 \mathrm{mg}$ awalnya dan selanjutnya diberikan setengah dosis induksi propofol yaitu $20 \mathrm{mg}$. Intubasi dilakukan dengan pemberian pelumpuh otot atracurium $10 \mathrm{mg}$. Saat tindakan laringoskopi dan intubasi dan tidak didapati gejolak hemodinamik lebih dari

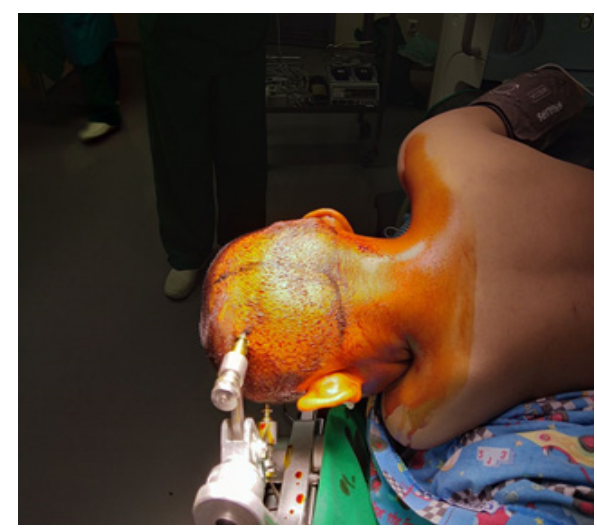

Gambar 2. Posisi Parkbench

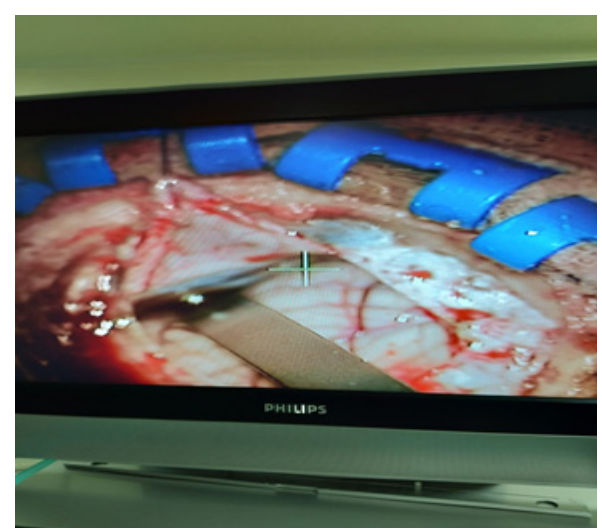

Gambar 3. Slack Brain

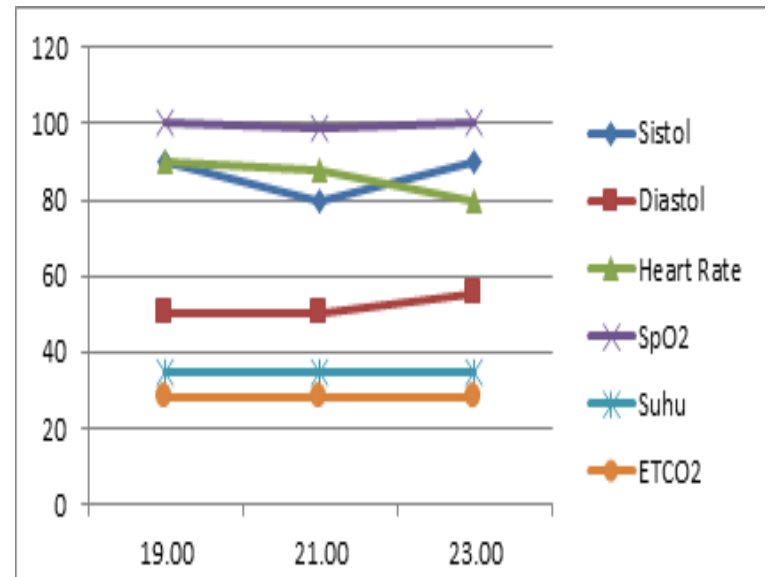

Gambar 2.4 Monitoring Intraoperatif

$20 \%$. Pemeliharaan anestesi dengan $\mathrm{O}_{2}+$ udara + sevofluran 1,5-2 \% dengan fraksi oksigen 50\%. Propofol kontinyu $6 \mathrm{ml} / \mathrm{jam}$, atracurium $4 \mathrm{mg} / \mathrm{jam}$. Intraoperatif diberikan manitol 50cc. Monitoring tanda-tanda vital selama operasi. Tekanan darah berkisar antara $75-100 / 40-60 \mathrm{mmHg}$, denyut jantung berkisar $70-90 \mathrm{x} /$ menit, saturasi oksigen 95-100 \%. Kontrol ventilator dengan modus Asist Volume, $\mathrm{FiO}_{2} 50 \%$, RR 20x/menit, End tidal $\mathrm{CO}_{2}$ menunjukkan $\mathrm{PaCO}_{2} 27 \mathrm{mmHg}$. Jumlah urin 50 cc, dan warna urin kuning jenih. Reseksi tumor dilakukan selama 4 jam. Perdarahan selama operasi sekitar $10 \%$ atau sekitar $140 \mathrm{ml}$, selama operasi hemodinamik relatif stabil. Selama tindakan pembedahan dipertahankan otak dalam kondisi kempes (slack brain). Tindakan tidak banyak manipulasi operator bedah.

\section{Pengelolaan Pascabedah}

Pasca bedah, intubasi tetap dipertahankan dengan waktu selama enam jam selama perawatan di Unit Perawatan Intensif (UPI) dengan pertimbangan operasi di daerah batang otak yang berisiko terjadi perdarahan dan pembengkakan akut dari struktur-struktur jaringan otak. Selain itu selama operasi juga sempat terjadi periode takikardia dan hipotensi yang di duga akibat manipulasi yang berlebihan pada struktur parenkim otak dan adanya perdarahan akut, dan operasi berlangsung selama 4 jam. Selama perawatan di UPI pasien dilakukan kontrol ventilasi dengan sedasi propofol $6 \mathrm{mg} / \mathrm{jam}$ dan analgesia fentanyl kontinyu dengan target Ramsay 2. Setelah perawatan selama 6 jam di 
UPI dilakukan weaning dan dilakukan ekstubasi setelah pasien sadar baik dan napas adekuat. ${ }^{16}$

\section{Pembahasan}

Operasi reseksi tumor pineal body dilakukan sesudah pemasangan VP-shunt oleh karena adanya hidrosefalus. Hidrosefalus dialami pasien karena terdapatnya sumbatan di ventrikel III sehingga meningkatkan tekanan intrakranial dengan adanya gejala nyeri kepala yang semakin lama semakin berat. Hidosefalus pada umumnya ditatalaksana dengan pembedahan, dengan pilihan jangka pendek meliputi drainase ekstraventrikular atau lumbar sebagai penghubung dengan solusi yang lebih permanen, seperti pemasangan endoscopic third ventriculostomy atau ventriculoperitoneal shunt (VP). Beberapa seri kasus telah menilai manfaat $V P$-shunt pada pasien dengan glioblastoma. Suatu penelitian meninjau luaran 16 pasien yang mengalami ventrikulomegali nonobstruktif yang menyertai glioblastoma progresif dan menemukan bahwa VP-shunt efektif untuk mengembalikan fungsi motorik dan kognitif. Namun, dilaporkan adanya tingkat morbiditas terkait shunt yang cukup tinggi, termasuk infeksi dini dan lanjut. ${ }^{1}$ Walaupun berbagai pendekatan untuk tumor pada ventrikel III posterior telah dikenalkan, namun hanya tiga pendekatan yang sering digunakan. Pendekatan infratentorialsupraserebelar memberi keuntungan berupa ruang yang alami antara serebelum dan tentorium. Pendekatan supratentorial meliputi intrahemisfer-transcallosal dan occipitaltranstentorial. Memilih pendekatan pembedahan yang optimal tergantung pada letak anatomi tumor serta pemilihan dan pengalaman dokter bedah. Perbaikan teknik pembedahan memberi dampak perbaikan pula pada hasil pembedahan untuk tumor yang jarang ini.

Glandula Pineal sering disebut mata ketiga, merupakan kelenjar endokrin kecil pada otak vertebrata. Kelenjar pineal memproduksi serotonin hormon yang mempengaruhi modulasi bangun dan tidur. Terletak di dekat titik tengah otak diantara dua hemisfer di celah antara kedua thalamus. ${ }^{2}$ Tujuan pembedahan pada tumor pineal

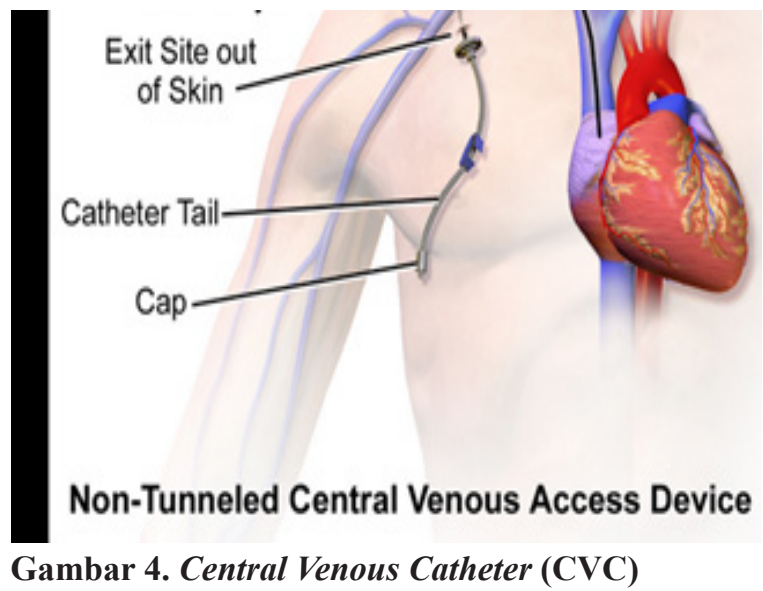

tergantung klinis dan situasi individual. Tujuan pertama adalah untuk menegakan diagnosis histologi. Pasien dengan germ cell maligna, biasanya dilakukan preoperatif dengan radioterapi dan kemoterapi. Reseksi tumor membuat pengurangan efek massa dan meningkatkan respon terhadap terapi adjuvant untuklesi maligna. Untuk tumor jinak, dapat dilakukan reseksi total. ${ }^{2-4}$

Pasien menunjukkan adanya disfungsi saraf kranial atau batang otak seperti sering sakit kepala, mual muntah, badan spasme, dan sering infeksi pernafasan sehingga sering berobat ke dokter anak yang tak kunjung sembuh. Pada hampir semua literatur, sebaiknya CVC dipasang untuk operasi tumor otak, namun pada pasien ini karena keterbatasan fasilitas tidak adanya CVC untuk anak maka dipasang 2 jalur infus yaitu di tangan kanan dan kaki kanan. Jadi masih bisa diganti penggantian cairan dengan 2 jalur infus dengan syarat monitoring ketat dan langsung segera digantikan cairan karena perdarahan. Untuk mengetahui bahwa cairan yang diberikan cukup, tekanan darah, denyut jantung, jumlah dan warna urin output, dan grafik plethismograp merupakan hal yang dapat dinilai. Central Venous Catheter atau biasa disebut central line access catheter adalah kateter yang ditempatkan ke dalam vena besar di leher (vena jugularis interna), vena subklavia atau vena femoralis.

Indikasi pemasangan CVC diperlukan untuk pemberian cairan, nutrisi, obat-obatan dengan konsentrasi pekat dan iritatif. Untuk resusitasi, 
cairan intravena dengan volume besar dapat secara cepat diberikan melalui kateter vena sentral dengan ukuran 8,5 Fr karena kecepatan aliran yang tinggi. Kesulitan pemasangan kateter vena perifer pada pasien dengan syok karena vasokonstriksi perifer merupakan salah satu indikasi pemasangan CVC. Pemberian obatobatan pada resusitasi jantung paru lebih efektif melalui kateter vena sentral dibandingkan vena perifer karena obat-obatan tersebut langsung mempengaruhi jantung dan didistribusikan ke seluruh tubuh. Indikasi lainnya adalah pemberian agen intravena yang dapat mengiritasi dan mengakibatkan sklerosis vena perifer seperti larutan kalium klorida, nutrisi parenteral total, obat kemoterapi dan vasopressor. Pengukuran tekanan vena sentral, tekanan arteri pulmonal, hemodialisis dan plasmapharesis adalah indikasiindikasi lain pemasangan CVC. Pada prinsipnya tidak ada kontraindikasi absolut pemasangan kateter vena sentral. Salah satu keadaan yang merupakan kontraindikasi pemasangan adalah pada pasien dengan koagulopati berat atau trombositopenia. Pada pasien-pasien dengan keadaan ini, vena femoral dan vena jugularis interna merupakan lokasi yang dianjurkan untuk pemasangan CVC karena perdarahan dari lokasi ini dapat dikontrol dengan penekanan namun tetap ada risiko untuk terjadinya hematoma yang besar dan mengganggu jalan nafas. Kontraindikasi lain dari pemasangan CVC yaitu infeksi pada lokasi pemasangan, adanya fistula arteriovena ipsilateral untuk hemodialisa, trombosis vena disekitar lokasi pemasangan. Teknik Seldinger telah menjadi pendekatan standar pemasangan kateter vena sentral. Teknik ini menggunakan penuntun melalui jarum akses, dimana penuntun ini akan memfasilitasi masuknya kateter ke dalam vena. ${ }^{5}$

Komplikasi yang dapat terjadi dibagi menjadi 3 kelompok besar yaitu: mekanik, infeksi, thrombosis atau emboli. Komplikasi mekanik biasanya adalah hasil langsung dari prosedur pemasangan dan dapat diketahui dalam waktu singkat. Salah satu yang sering terjadi adalah aritmia atrial, insiden komplikasi ini adalah $41 \%$. Aritmiayang terjadibiasanyatidak mengakibatkan efek yang serius, insiden terjadi aritmia ventricular maligna adalah rendah. Komplikasi terjadi karena kabel penuntun atau kateter yang terlalu dalam sampai ke atrium kanan. Komplikasi mekanik lain yang sering adalah tertusuknya arteri, biasanya terjadi pada penusukan di vena femoralis dan jugularis interna, namun bila arteri subklavia tertusuk, perdarahan yang terjadi susah dikendalikan dengan tekanan sehingga sering mengakibatkan hematoma ekstrapleural ataupun hemothoraks. Pneumothoraks yang terjadi akibat kateterisasi vena sentral biasanya dapat ditangani dengan observasi ketat serta kontrol rontgen thoraks kecuali bila pasien mendapat ventilasi mekanik dengan tekanan positif. Adanya udara di mediastinum atau subkutan (emfisema) adalah tanda terjadi robekan pada pleura. ${ }^{5}$

Dalam pemasanagan CVC pada tumor otak harus dipertimbangkan komplikasi yang dapat ditimbulkan. Gangguan hemodinamik dan respirasi yang terjadi setelah pemasangan CVC pada vena jugularis interna dan subklavia harus segera dicurigai suatu pneumothoraks tipe tension dan segera dilakukan dekompresi. Emboli udara dapat terjadi dengan insidens $0,1 \%$, dikarenakan pada saat pemasangan atau pelepasan kateter ujung kateter terhubung dengan udara. Hal ini dapat dihindari dengan prosedur yang benar seperti penggunaan posisi Trendelenburg, pembilasan kateter dengan cairan salin, serta penutupan semua ujung kateter sebelum pemasangan. Bila emboli terjadi, pasien harus segera diposisikan Trendelenburg dengan sudut yang curam serta posisi miring ke kiri, diberikan oksigen $100 \%$ dan dukungan hemodinamik bila diperlukan. Aspirasi udara dari kateter dapat dilakukan meskipun kemungkinan berhasilnya kecil. Malposisi dari kateter, yang didefinisikan sebagai posisi ujung kateter yang tidak tepat. kateter yang tersumbat, thrombosis, emboli, maupun perforasi vena dengan hemothoraks atau cairan infus di rongga mediastinum, atau bahkan perforasi atrium kanan dengan tamponade dapat terjadi bila ujung kateter tidak paralel dengan lumen vena cava superior. Hal-hal tersebut dapat dideteksi dengan rontgen thoraks paska tindakan dan bila terjadi harus segera dilakukan tindakan reposisi atau penggantian kateter dengan penuntun. Kateterisasi juga dapat mencederai sistem limfatik yaitu duktus thoracicus yang 
memasuki vena diperbatasan antara vena subklavia kiri dan vena jugularis interna kiri. Cedera ini biasanya tidak disadari sampai terjadi efusi pleura dengan kilothoraks pada foto rontgen. Komplikasi ini dapat ditangani dengan drainase dan pembatasan diet namun dapat juga memerlukan operasi ligasi untuk kontrol definitif. Komplikasi emboli dan trombosis dapat terjadi setelah pemasangan kateter terutama pada pasien dengan keganasan (insiden sampai dengan $36 \%$ ). Trombosis lebih sering terjadi pada vena jugularis interna dan femoralis dibandingkan dengan vena subklavia. Trombosis vena dalam pada ekstrimitas atas merupakan $15 \%$ dari kasus thrombosis vena dalam di ruang terapi intensif dan semuanya berkaitan dengan kanulasi vena subklavia dan jugularis interna. Faktor risiko terjadinya trombosis meningkat pada pemasangan CVC di vena jugularis interna, tanpa dilakukan heparinisasi, serta pemberian emulsi lipid. Walaupun sering tanpa gejala namun trombosis yang terjadi perlu segera diketahui dan ditangani sebab merupakan risiko terjadinya emboli paru. ${ }^{5}$

Posisi tindakan reseksi tumor pineal body yaitu parkbench, dimana tubuh pasien dibalikan agak telungkup, bahu bagian atas menjadi condong ke dalam dan memberikan akses yang lebih leluasa bagi operator bedah. Ada beberapa posisi yang biasanya dilakukan pada operasi di daerah fossa posterior diantaranya: posisi lateral, posisi telungkup (prone), posisi duduk (sitting) dan posisi telentang (supine) menyebabkan sindroma Parinaud. Posisi lateral dikatakan banyak dipilih untuk pendekatan pada daerah Cerebro Pontin Angle (CPA), namun sering menyebabkan permasalahan pada bahu pasien dan kelumpuhan saraf popliteal akibat kaki yang menggantung. ${ }^{6-8}$

Umumnya curah jantung dipertahankan stabil, ada sedikit penurunan resistensi vascular sistemik. Penurunan complain paru bawah dapat menyebabkan penurunan fungsional residual capacity (FRC). Pada posisi lateral dan parkbenchter dapat resiko cedera pleksus brachialis kalau lengan atas ditarik kebawah untuk memudahkan akses ke daerah mastoid dan tekanan pada saraf di daerah aksila. Pemutaran leher dapat menyebabkan regangan dan kerusakan plexus brachialis. Fleksi leher yang ekstrim dapat menimbulkan quadriplegia, terutama pada posisi duduk, dan keadaan ini dapat diperburuk dengan adanya hipotensi. Untuk dokter anestesi posisi ini lebih menguntungkan karena ada akses langsung kemuka, dada danjalan nafas. Baik digunakan pada pasien obese atau pasien dengan kyphosis, karena ventilasi lebih efisien dan complain lebih baik. ${ }^{6,9}$

Emboli udara Venous Air Embolism (VAE) jarang dijumpai. Bantal/guling digunakan untuk menghindari penekanan pada pembuluh darah dan syaraf. Namun demikian ada beberapa resiko dari posisi diantaranya pembuntuan vena dan leher yang terpelintir, selain itu walaupun angka kejadiannya lebih rendah dari posisi duduk tetapi tetap beresiko terjadinya VAE. ${ }^{7,9}$ VAE adalah satu dari beberapa hal yang paling diantisipasi oleh seorang neuroanestesi. Angka kejadian VAE sangat tergantung dari posisi dari pasien pada saat operasi, dimana angka kejadian tertinggi pada posisi duduk 40-45\% sedangkan pada posisi lateral, telungkup dan parkbench angka kejadiannya menurun menjadi 10-15\%. Oleh karena pasien ini akan dilakukan pada posisi parkbench maka pasien ada pada resiko sedang untuk terjadinya VAE. VAE juga berbanding lurus dengan besarnya beda ketinggikan antara jantung dan lapangan operasi, dimana semakin tinggi letak lapangan operasi terhadap jantung, maka angka kejadian VAE akan semakin meningkat. Hal ini karena perbedaan ketinggian antar lapangan operasi dan jantung akan menyebabkan terjadinya tekanan subatmosfer pada pembuluh darah yang terbuka, sehingga terjadi penyedotan udara dari luka operasi ke dalam pembuluh darah (sucking wound). VAE dapat dimonitor dengan beberapa metode yaitu kondisi hemodinamik seperti tekanan darah, tekanan vena sentral Central Venous Pressure (CVP), tekanan arteri pulmonal, precordial doppler ultrasound, end tidal gas monitoring, dan transesophagial echocardiography (TEE). ${ }^{7,10}$

Kasus-kasus dengan resiko yang tinggi disarankan untuk menggunakan $\mathrm{ETCO}_{2}$. Pada kasus ini kejadian VAE termasuk dalam resiko sedang oleh karena itu kejadian VAE dimonitoring dengan menggunakan kateter vena sentral, $\mathrm{ETCO}_{2}$ dan 
saturasi oksigen. Tidak ada tindakan yang $100 \%$ efektifuntukmencegah terjadinya VAE pada posisi operasi yang menempatkan lapangan operasi lebih tinggi dari pada jantung. Tetapi insiden dan keparahan dari VAE dapat diturunkan dengan mengkontrol nafas dengan ventilasi kendali tekanan positif, hidrasi yang adequat, pengaturan posisi sedemikian hingga sehingga posisi kepala paling mendekati jantung dengan lapangan operasi yang masih tetap baik, teknik operasi yang sangat berhati-hati pada saat melakukan dissection dan penggunaan bone wax yang liberal, hindari penggunaan $\mathrm{N}_{2} \mathrm{O}$ terutama pada pasien yang diketahui memiliki defect intrakardiak dan hindari penggunaan obat-obatan yang meningkatkan kapasitasi vena (nitrogliserida). ${ }^{11,12}$ Tindakan-tindakan yang dilakukan jika terjadi VAE intraoperatif: Informasikan kepada operator bahwa terjadi VAE, hentikan $\mathrm{N}_{2} \mathrm{O}$ dan tingkatkan konsentrasi oksigen, rubah teknik anestesi, minta pada operator untuk membanjiri lapangan operasi dengan air, lakukan penekanan pada vena jugularis, lakukan aspirasi pada kateter vena sentral, persiapkan support kardiovaskular, rubah posisi pasien. ${ }^{13}$ Pada pasien ini, kami tidak dapat menggunakan monitoring neurofisiologi karena adanya keterbatasan alat yang tersedia. Resiko terjadinya cedera pada saraf-saraf di batang otak sangatlah tinggi, karena sebagian besar saraf-saraf otak tersebut letaknya disekitar batang otak terutama pons dan midbrain. Oleh karena itu, sebenarnya diperlukan monitoring dari fungsi saraf-saraf otak tersebut pada saat intraoperatif. Monitoring yang didapat digunakan diantaranya somatosensory evoked potensial (SSEPs), Brain steam auditory evoked respons (BAERs), dan spontaneous and evoked electromyogram (EMG). Saraf otak V,VII dan X biasanya dapat dimonitoring dengan EMG dan khusus untuk saraf otak VIII biasanya dimonitoring dengan BAERs. ${ }^{13}$

Jika diputuskan untuk menggunakan monitoring saraf-saraf otak intraoperatif, maka teknik anestesi yang dilakukan harus disesuaikan sehingga tidak menyebabkan gangguan pada proses monitoringnya. Hal yang perlu diingat oleh seorang dokter anestesi adalah obat-obat anestesi dapat mempengaruhi pembacaan evoked potentials dan EMG, dimana pelumpuh otot sangat mengganggu interpretasi dari EsMG, $\mathrm{N}_{2} \mathrm{O}$ dan dosis tinggi voletile dapat mempengaruhi SSEPs. ${ }^{14}$ Disarankan untuk menggunakan total intravenous anestesia (TIVA) dengan propofol dan fentanyl untuk mendapatkan pasien dengan tanpa pergerakan dan monitoring neurofisiologi yang baik. ${ }^{15,16}$

Durante operasi pasien saat manipulasi di tumor otak pasien mengalami takikardia tetapi tidak berlangsung lama, yang diduga tejadi perdarahan. Saat terjadi takikardia dan hipotensi dilakukan penggantian cairan dan komunikasi dengan operator dan kembali normal setelah operator mengurangi manipulasinya. Selain posisi operasi, masalahlain pada operasi tumor pineal body adalah dekatnya operasi pada saraf kranial dan struktur batang otak yang mengatur fungsi respirasi dan kardiovaskular. Manipulasi bedah sering menimbulkan ketidakstabilan kardiovaskular. Angka kejadian intraoperatif pada operasi tumor otak pineal body yaitu kejadian takikardia 4,34\%, bradikardia ditemukan signifikan yaitu 14,5\%, hipertensi 10,14\%, dan hipotensi $11,6 \%$. Hal ini diperkirakan karena terjadinya manipulasi pada dasar ventrikel empat, medullary reticular formation, akar saraf trigeminus, akar saraf vagus dan saraf otak no IX..$^{16,17}$

Bila nervus V (nervus trigeminalis) distimulasi bisa terjadi bradikardia berat dan hipertensi sedangkan bila distimulasi nervus IX atau $\mathrm{X}$ bisa terjadi bradikardi dan hipotensi. Selain nervus kranialis stimulasi terhadap daerah periventrikulaer substansia grisea, formasio retikularis, nucleus traktus solitorius dapat menyebabkan hipertensi hebat. Sedangkan hipotensi terjadi akibat penekanan medulla oblongata dan pons. ${ }^{18,19}$ Episode hipotensi pada operasi bedah saraf tidak boleh dianggap remeh, jika terjadi maka secepat mungkin harus ditangani. Hal ini karena aliran darah otak bergantung pada tekanan arteri serebral dan resistensi pembuluhpembuluh darah serebral. Aliran darah otak ratarata sekitar 50-54 ml/100 gr jaringan/menit yang mana dipertahankan oleh autoregulasi antara mean arterial pressure (MAP) $50-150 \mathrm{mmHg}$. Mean arterial pressure kurang dari $50 \mathrm{mmHg}$, 
maka aliran darah otak akan mengikuti tekanan darah dari pasien, jika aliran darah otak $<20$ $\mathrm{ml} / 100$ gr jaringan/ menit akibat MAP kurang dari $50 \mathrm{mmHg}$, maka elektroensefalografi (EEG) menunjukan tanda iskemik. Bila aliran darah otak 6-9 ml/100 gr/menit, $\mathrm{Ca}_{2}+$ masuk ke dalam sel. Jika aliran darah ke otak 12-20 ml/ 100 gr jaringan/ menit, maka akan terbentuk episode penumbra, yaitu suatu episode iskemia reversible, yang jika dibiarkan dapat menyebabkan terjadinya episode infarction yang sifatnya nonreversible. ${ }^{20}$

Kemungkinan kehilangan darah yang banyak pada pasien ini. Pada pasien ini, letak tumor dekat dengan sinus, kemudian vaskularisasi dari massa menurut ahli bedah juga banyak. Selain itu ahli bedah yang akan mengerjakan juga mempunyai reputasi yang baik dalam hal perdarahan, oleh karena itu pasien ini untuk peredarahan kami masukkan dalam resiko menengah, dan tetap kami siapkan persediaan darah untuk mengganti kehilangan darah. Untuk memperkirakan jumlah pendarahan yang mungkin terjadi, maka sebaiknya mempertimbangkan keterlibatan sinus, vaskularitias dari massa, dan skill \& riwayat ahli bedahnya. Pasca operasi pasien tetap dipertahankan intubasi tidak langsung dilakukan ekstubasi dengan pertimbangan operasi di daerah batang otak yang berisiko terjadi perdarahan dan pembengkakan akut dari struktur-struktur fossa posterior. Selain itu durante operasi juga sempat terjadi periode takikardia dan hipotensi yang dicurigai akibat manipulasi yang berlebihan pada nervus kranialis dan struktur batang otak. Selama perawatan di ruang terapi intensif pasien dilakukan kontrol ventilasi dengan sedasi propofol dan analgesia fentanyl kontinyu dengan target Ramsay 2. Setelah perawatan selama 6 jam di ruang terapi intensif dilakukan weaning dan dilakukan ekstubasi setelah pasien sadar penuh dan hemodinamik stabil.

\section{Simpulan}

Tumor pineal body adalah suatu tumor otak yang jarang ditemukan, dengan insidensi hanya10\%. Perdarahan pada kasus reseksi tumor pineal body terjadi pada sekitar $5-10 \%$ kasus operasi sehingga pemasangan CVC yang dilakukan sebelum operasi harus dilakukan dengan pertimbangan hati-hati terhadap manfaat dan komplikasi dari tindakan pemasangan $\mathrm{CVC}$ itu sendiri. Pengelolaan pasien reseksi tumor pineal body dengan posisi parkbench tanpa pemasangan CVC dapat dilakukan dengan monitoring ketat dan segera mengatasi masalah tiap kejadian selama operasi. Pada posisi parkbench angka kejadian Venous Air Embolism menurun menjadi $10-15 \%$, sehingga adanya CVC bermanfaat untuk mengatasi hal ini

\section{Daftar Pustaka}

1. Castro, BA. Ventriculoperitoneal shunting for Glioblastoma: risk factors, indications and efficacy. Neurosurgery. 2017; 8: 421-30.

2. Lozier A, Bruce J. Surgical approaches to posterior third ventricular tumors. Neurosurg Clin N Am. 2003;14(4):527-45.

3. Macchi M, Bruce J. Human pineal physiology and functional significance of melatonin. Front Neuroendocr. 2004;25(3-4):177-95.

4. Behari S, Garp P, Jaiswal S, Nair A, Naval R, Jaiswal A. Major surgical approaches to the posterior third ventricular region: A pictorial review. J Pediatr Neurosci. 2010;5(2):97101.

5. Pepe A, . Timing of central venous catheter exchange and frequency of bacteremia in burn patients. Journal of Burn Care and Research. 2007; 28: 859-60.

6. Rachman I, Bisri T. Penatalaksanaan anestesi pada tindakan bedah tumor fossa posterior: Serial Kasus. J Neuroanestesi Indones. 2016;5(1):1-12.

7. Goma H. Anesthetic considerations of brain tumor surgery. Dalam: Abujamra AL, Eds. diagnostic techniques and surgical management of brain tumors. Egypt: InTech; 2011

8. Himmelseher S, Pfenninger E. Anaesthetic 
management of neurosurgical patients. Curr Opin Anaesthesiol. 2001;14(5):483-90.

9. Jagannathan SS, Krovvidi H. Anaesthetic considerations for posterior fossa surgery. Contin Educ Anaesthesia, Crit Care Pain. 2014;14(5):202-06.

10. Dinsmore J. Anesthesia for elective neurosurgery. Br J Anesth. 2007;99(1):6774.

11. Gheorghita E, Ciurea J. Balanescu B. Considerations on anesthesia for posterior fossa-surgery. Rom Neurosurgery. 2012;19(3):183-92.

12. Pederson D, Peterfreund R. Anesthesia for posterior fossa surgery. Dalam: Newfield P, Cottrel J, eds. Handbook of Neuroanesthesia. 5th ed. Philadelphia: Lippincott Williams \& Wilkins; 2012:136-47.

13. Ibrahim AS, Mahmoud YA. History of neurosurgery in Jordan. World Neurosurgery. 2016: 655-59.

14. Bruce J, Ogden A. Surgical strategies for treating patient with pineal region tumors. J Neurooncol. 2004;69:221-36.
15. SchlichterR,SmithD.Anesthetic management for posterior fossa surgery. Dalam: Cottrell J, Pate P, eds. Neuroanesthesia. 6th ed. Elsevier; 2017.

16. Smith D. Anesthetic management for posterior fossa surgery. Dalam: Cotrell JE, Young WL, eds. Neuroanesthesia, 5th ed, Mosby. 2010:203-17.

17. Sabbagh A, Al-Yamany M, Bunyan R, Takrouri M, Radwan S. Neuroanesthesia management of neurosurgery of brain stem tumor requiring neurophysiology monitoring in an iMRI OT setting. Saudi J Anaesth. 2009;3(2).

18. Bisri T. Anestesi untuk operasi fossa posterior. neuroanestesia, Bandung. 1997:153-63.

19. Lumbantobing. Neurologi klinik pemeriksaan fisik dan mental. Jakarta: Badan Penerbit FKUI; 2015.

20. Bisri D, Bisri T. Anestesi untuk operasi tumor otak: supratentorial infratentorial. Pertama. Bandung: Fakultas Kedokteran Universitas Padjadjaran; 2016 Bandung: Fakultas Kedokteran Universitas Padjadjaran; 2016. 